\title{
A patient information booklet about anesthesiology improves preoperative patient education
}

\author{
[Une brochure d'information destinée aux patients au sujet de l'anesthésiologie \\ améliore leurs connaissances préopératoires]
}

Angela Cheung BSc, Barry A. Finegan FRCPC, Clint Torok-Both FRCPC, Niamh Donnelly-Warner FRCPC, Jelka Lujic MD

Purpose: Preadmission clinics provide a limited timeframe in which patients can discuss the risks and benefits of various forms of anesthesia. We hypothesized that the provision of a patient information booklet would clarify and reinforce salient perioperative topics related to anesthesia.

Methods: A prospective study was carried out in two phases. In Phase I, anesthesiologists were surveyed to determine the key topics routinely discussed during a preadmission clinic visit. Subsequently, we developed an illustrated booklet highlighting some of the topics identified during the survey. In Phase II, the booklet was evaluated by a questionnaire designed to assess patient knowledge about perioperative issues. This questionnaire was administered to a control group of patients who did not receive the booklet and a study group who received the booklet. Statistical significance was established at $P<0.05$.

Results: In Phase I, 65 anesthesiologists completed the survey of their current practice in the preadmission clinic. The survey revealed no uniformity in overall information provision, but indicated that certain issues were routinely discussed with patients. In Phase II, 322 patients were enrolled. Patients in the study groups scored significantly higher on the knowledge assessment questionnaire than did patients in the control group. Both education and country of origin influenced the scores of patients in the control group, but not in the study group.

Conclusion: A simple, illustrated patient information booklet, when appropriately written and illustrated, is an effective means of standardizing the communication of the risks and benefits of anesthesia in a preadmission clinic. A booklet with a focus on plain language usage and simple illustrations appears to be an advantageous educational tool even in culturally diverse populations.

CAN J ANESTH 2007 / 54: 5 / pp 355-360
Objectif: Les cliniques de préadmission permettent un temps limité pour discuter avec les patients des risques et des bienfaits des diverses formes d'anesthésie. Nous avons émis l'hypothèse qu'en fournissant aux patients une brochure d'information, cela clarifierait et renforcerait la compréhension des thèmes périopératoires fondamentaux relatifs à l'anesthésie.

Méthode : Une étude prospective a été menée en deux phases. Durant la phase I, les anesthésiologistes ont été interrogés afin de déterminer les thèmes clés régulièrement discutés lors d'une visite en clinique de préadmission. Par la suite, nous avons conçu une brochure illustrée mettant en évidence certains des thèmes identifiés pendant le sondage. Durant la phase II, la brochure a été jugée sur la base d'un questionnaire visant à évaluer les connaissances des patients au sujet des questions périopératoires. Ce questionnaire a été distribué à un groupe témoin de patients n'ayant pas lu la brochure et à un groupe d'étude qui l'a reçue. La signification statistique $a$ été fixée à $P<0,05$.

Résultats : Durant la phase I, 65 anesthésiologistes ont répondu au sondage sur leur pratique actuelle en clinique de préadmission. L'étude n'a pas révélé d'uniformité dans la distribution d'informations dans son ensemble, mais a indiqué que certaines questions étaient régulièrement abordées avec les patients. La phase II de l'étude a impliqué 322 patients. Les patients du groupe d'étude ont affiché des résultats nettement plus élevés dans le questionnaire d'évaluation des connaissances que le groupe témoin. Le niveau d'éducation et le pays d'origine ont tous deux influencé les résultats des patients du groupe témoin, mais pas ceux du groupe d'étude.

Conclusion: Une brochure d'information simple destinée aux patients, si elle est bien écrite et illustrée, devient un moyen efficace de standardiser la communication, en clinique de préadmission, des risques et bienfaits liés à l'anesthésie. Une brochure utilisant un langage clair et des images simples semble constituer un outil éducationnel avantageux même auprès de populations multiculturelles.

From the Department of Anesthesiology and Pain Medicine, University of Alberta, Edmonton, Alberta, Canada. Address correspondence to: Dr. B.A. Finegan, Department of Anesthesiology and Pain Medicine, 8-120 Clinical Sciences Building,

Edmonton, Alberta T6G 2G3, Canada. Phone: 780-407-8887; Fax: 780-407-3200; E-mail: chassist@ualberta.ca Supported by Departmental funding. Accepted for publication December 10, 2006. Revision accepted February 2, 2007. 
A recent survey of the general public indicated that the majority of individuals would prefer to see an anesthesiologist prior to surgery, and that a significant minority $(20 \%)$ have substantial concerns regarding brain damage, intraoperative awareness, and memory loss associated with anesthesia. ${ }^{1}$ When questioned specifically about regional anesthesia, $27 \%$ of respondents were very concerned about permanent paralysis, back injury, and perioperative pain should a regional technique be used for a knee surgery procedure. ${ }^{2}$ These data suggest that there is a great degree of ignorance among the general public around anesthesia-related issues.

Media-based interventions that convey anesthesia-related information have been shown to improve patient knowledge and alleviate anxiety. ${ }^{3-5}$ There has, however, been no attempt to clearly identify the key facts that should be conveyed to a patient during a preoperative interview. In addition, despite the fact that illiteracy is an ongoing problem, few studies address methods that may enhance patient comprehension of educational materials. In the case of written material, it is essential for the language to be comprehensible to those of limited reading ability. The recent Canadian Adult Literacy and Life Skills Survey indicates that $15 \%$ of the population have very poor reading skills and are unable to determine the correct amount of medication to give to a child from information printed on a package. ${ }^{4} \mathrm{~A}$ further $27 \%$ of the population are functionally illiterate; in other words, they are capable of reading, but have poor comprehension skills. Combining written material with appropriate images has been shown to be significantly more effective than text alone in enhancing comprehension. ${ }^{5}$

This study was designed to determine the key topics that anesthesiologists routinely discuss with patients in a preadmission clinic, and to test the effectiveness of a graphically illustrated booklet specifically written at a Grade 6 reading level in improving patient's knowledge about the perioperative period.

\section{Methods}

Research ethics board approval was obtained and all participants in the study gave written informed consent.

In Phase I, a questionnaire was distributed to both staff and resident anesthesiologists in a tertiary care hospital preadmission clinic (University of Alberta). Completion of the questionnaire was voluntary. The questions were designed to assess what information was routinely imparted during a preadmission visit, focusing on general concepts in anesthesia (including pain management), preoperative instructions,
TABLE I Questionnaire completed by anesthesiologists in Phase I

\begin{tabular}{|c|c|c|c|}
\hline \multirow[t]{2}{*}{ Question } & \multicolumn{3}{|c|}{ Results (\%) } \\
\hline & Always & Sometimes & Never \\
\hline $\begin{array}{l}\text { 1 Do you explain the difference } \\
\text { between regional and general } \\
\text { anesthesia when the option is possible } \\
\text { for the patient? }\end{array}$ & 95.4 & 4.6 & 0.0 \\
\hline $\begin{array}{l}2 \text { Do you explain which drugs the } \\
\text { patient should take before surgery } \\
\text { and which should be stopped? }\end{array}$ & 93.8 & 4.6 & 1.5 \\
\hline $\begin{array}{l}3 \text { Do you explain how the patient } \\
\text { will be monitored during and after } \\
\text { the surgery? }\end{array}$ & 32.3 & 50.8 & 16.9 \\
\hline $\begin{array}{l}4 \text { Do you explain the risk } \\
\text { of aspiration? }\end{array}$ & 6.2 & 60.0 & 33.8 \\
\hline 5 Do you explain NPO rules? & 58.5 & 23.1 & 18.5 \\
\hline $\begin{array}{l}6 \text { Do you explain the possible } \\
\text { risks of postoperative nausea and } \\
\text { vomiting? }\end{array}$ & 20.0 & 53.8 & 26.2 \\
\hline $\begin{array}{l}7 \text { Do you explain the possibility of } \\
\text { hoarseness after intubation? }\end{array}$ & 12.3 & 43.1 & 44.6 \\
\hline $\begin{array}{l}8 \text { Do you explain the possibility } \\
\text { of dental damage? }\end{array}$ & 33.8 & 61.5 & 4.6 \\
\hline $\begin{array}{l}9 \text { Do you explain the possibility of } \\
\text { pain with } i v \text { insertion? }\end{array}$ & 4.6 & 15.4 & 80.0 \\
\hline $\begin{array}{l}10 \text { Do you explain the possibility of } \\
\text { nerve compression? }\end{array}$ & 3.1 & 24.6 & 72.3 \\
\hline $\begin{array}{l}11 \text { Do you explain the possibility of } \\
\text { memory loss or concentration } \\
\text { problems after anesthesia? }\end{array}$ & 3.1 & 21.5 & 75.4 \\
\hline $\begin{array}{l}12 \text { Do you explain the possibility of } \\
\text { back pain after regional (epidural) } \\
\text { anesthesia? }\end{array}$ & 43.1 & 36.9 & 20.0 \\
\hline $\begin{array}{l}13 \text { Do you explain the risk of } \\
\text { headache after spinal or epidural? }\end{array}$ & 86.2 & 12.3 & 1.5 \\
\hline $\begin{array}{l}14 \text { Do you explain the potential need } \\
\text { for a blood transfusion? }\end{array}$ & 56.9 & 43.1 & 0.0 \\
\hline $\begin{array}{l}15 \text { Do you explain postoperative } \\
\text { pain management? }\end{array}$ & 90.8 & 7.7 & 1.5 \\
\hline $\begin{array}{l}16 \text { Do you explain the risk of } \\
\text { awareness during anesthesia? }\end{array}$ & 1.5 & 61.6 & 36.9 \\
\hline
\end{tabular}

$\mathrm{NPO}=$ nulla per os.

and complications (Table I). Respondents could answer in one of the following three ways: "Always", "Sometimes" or "Never". The data were analyzed and a booklet was designed to address the deficiencies and inconsistencies in information delivery identified between anesthesiologists.

In Phase II, a structured questionnaire was used to test the efficacy of the booklet in improving the knowledge of patients about perioperative issues. Patients were approached in the preadmission clinic, irrespective of the type of scheduled surgical proce- 
TABLE II Statements administered to patients in Phase II

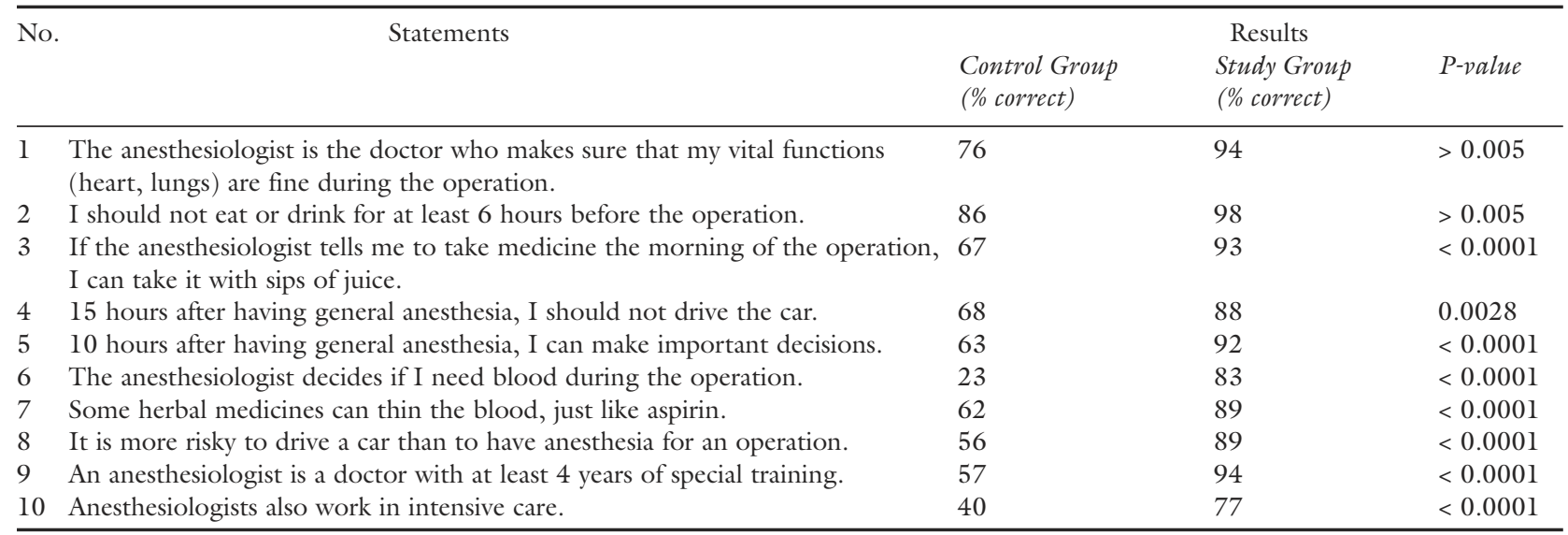

dure. Using a random numbers table, patients were assigned to receive the questionnaire only (control group) or to receive the information booklet (study group). The control group received the questionnaire immediately, while the study group received the questionnaire after reading the booklet. Furthermore, a subset of participants in both groups filled out the questionnaire after their anesthesia consultation.

\section{Information booklet}

The information booklet entitled "Patient Information Booklet About Anesthesia" from the Department of Anesthesiology and Pain Medicine at the University of Alberta (available as Additional Material at: www. cja-jca.org) consisted of ten pages of large print (font size 14) that introduced the role of the anesthesiologist, the procedural differences and the risks of general $v$ s. local anesthesia, the rationale for perioperative instructions and answers to frequent concerns about anesthesia. The text was edited to conform to a Grade 6 reading level and plain language principles. ${ }^{6}$ Artistic reproductions of hospital environments and relevant procedures were included in order to enhance understanding and the booklet's general appeal.

\section{Questionnaire}

We developed a ten-item questionnaire which was also at a Grade 6 reading level. The questionnaire was designed to assess knowledge retention of facts pertaining to the risks of anesthesia, perioperative instructions, and the role of the anesthesiologist (Table II).

Responses were recorded via a series of boxes corresponding to "Right", "Wrong" and "I don't know". One point was assigned for each correct answer and zero for the other two options.

\section{Statistical analysis}

An initial power analysis was performed based on a pilot experiment using 20 subjects. It was estimated that in order to detect a difference in the test score of 1 as significant ( $\alpha=0.05$ and power $90 \%$ ), approximately 150 subjects had to be enrolled in each group. Test scores and patient demographics are reported as medians. The significance of differences between the two test groups was determined using the MannWhitney test as data sets for scores did not have a normal distribution. Multiple logistical regressions were also conducted to determine whether factors in addition to experimental group influenced the final test score. For sub-group analysis, a non-parametric, oneway ANOVA (Kruskal Wallis) was performed to assess significance of differences in test scores between: a) subjects born within Canada, and those born outside the country; b) subjects who completed the questionnaire either before or after seeing the anesthesiologist; and c) subjects who had different education levels judged by whether or not they had completed high school. If ANOVA was significant, a Dunn's multiple comparisons test was used as a post hoc test to evaluate differences among sub-groups.

\section{Results}

\section{Phase I}

Sixty-five anesthesiologists completed the anonymous 16-item questionnaire pertaining to current practice (demographics as in Table III). There were disparities in responses in virtually all subject areas (Table I). Subjects that were reliably discussed were the differences between regional and general anesthetics, medications to be taken or held preoperatively and the risk of headache following a spinal/epidural. While patients were told of nulla per os rules, anesthesiolo- 
TABLE III Demographics of anesthesiologists who completed the survey in Phase I

\begin{tabular}{lll}
\hline Gender & Male & $71 \%$ \\
& Female & $29 \%$ \\
Level of training & Staff & $54 \%$ \\
& Residents (Rl-R5) & $34 \%$ \\
\multirow{2}{*}{ Nationality } & Fellows & $12 \%$ \\
& Canadian born & $54 \%$ \\
& Other* & $56 \%$ \\
\hline
\end{tabular}

* Other countries of origin included Saudi Arabia, Israel, Australia, New Zealand, and France.

TABLE IV Demographics of patients studied in Phase II

\begin{tabular}{lll}
\hline & $\begin{array}{l}\text { Control Group } \\
n=161\end{array}$ & $\begin{array}{l}\text { Study Group } \\
n=161\end{array}$ \\
\hline $\begin{array}{ll}\text { Gender (\%) } \\
\text { Male }\end{array}$ & 57 & 55 \\
Female & 44 & 45 \\
Age (mean) & 58 & 54 \\
Education (\%) & & \\
No high school diploma & 33 & 30 \\
High school or above & 67 & 70 \\
Country of origin (\%) & & \\
Canadian born & 86 & 83 \\
Foreign born & 14 & 17 \\
\hline
\end{tabular}

TABLE V Influence of anesthesia consultation on median scores obtained in the questionnaire administered to the patients in Phase II

\begin{tabular}{lll}
\hline & $\begin{array}{l}\text { Before anesthesia } \\
\text { consultation }\end{array}$ & $\begin{array}{l}\text { After anesthesia } \\
\text { consultation }\end{array}$ \\
\hline Control group & $50 \%(n=71)$ & $80 \%(n=37) P<0.001$ \\
Study group & $90 \%(n=70)$ & $90 \%(n=35) P<0.01$ \\
& $P<0.001$ & $P<0.05$ \\
\hline
\end{tabular}

gists neglected to clarify the rationale behind them, namely, the risk of aspiration.

\section{Phase II}

A total of 397 patients were approached to participate. Of these, $61(15 \%)$ refused to participate because of medical problems, language barriers, emotional distress, privacy concerns or lack of time. Data from a further 14 participants (4\%) were excluded from analysis due to the receipt of incomplete questionnaires.

There was no significant difference between the two groups with regards to gender, age, income, or country of origin (Table IV). Patients in the control group performed poorly on the questionnaire, achieving a median score of 5; patients in the study group, however, obtained a median score of $9(P<0.0001$;
Table II). When responses to the individual questions were compared, questions 1, 2 and 4 were answered equally well by both the control and study groups. Neither education nor country of origin appeared to have an impact on the number of correctly answered questions in the study group. However, in the control group, both factors may have influenced participant understanding of the amount of training an anesthesiologist has undergone ( $60 \%$ of Canadian-born patients understood an anesthesiologist was a doctor with "at least four years of special training" vs $36 \%$ of those non-Canadian born) as well as the potential perioperative impact of herbal medicines (68\% vs 36\%).

Patients received the booklet and questionnaire at different points during their stay in the preadmission clinic. When patients completed the questionnaire prior to their anesthesia consultation, there was a significant difference between the median scores of the control and study groups $(P<0.001)$. When both groups completed the questionnaire following the anesthesia consultation, the difference between their median scores became non-significant. Score comparison between control group participants who completed the questionnaire after the consultation with study group participants who completed the questionnaire before the consultation provides information on the efficacy of the consultation and the booklet in patient education. Although we did not have access to this information in all the patients enrolled, the available data (213 patients) demonstrate that both methods may have similar levels of efficacy in the tested spheres of knowledge (Table V).

\section{Discussion}

We have confirmed that appropriately written and graphically illustrated reading material can be an efficient and effective means of educating patients about the role of the anesthesiologist and anesthetic management. There were a number of key steps in the development of our booklet, namely, an assessment of need, an examination of the most ideal medium, and a determination of effectiveness.

The initial step in the development of material for patient education is the identification of the key facts that need to be delivered. The process of deciding what information is crucial in any particular instance is not an easy one, a concept supported by the adversarial nature of our judicial system. In this study, we sought, by the use of a questionnaire, to determine by direct inquiry the key facts that anesthesiologists routinely impart to patients during a preoperative consultation. Our findings, not surprisingly perhaps, suggest that there is no consensus around exactly what should be 
discussed with patients. We found that potential complications that incur the highest risk of legal jeopardy, such as inadvertent nerve compression with residual weakness and unforeseen awareness during general anesthesia, 7,8 were not "always" considered topics for discussion. In assessments of physician behaviour during consultations, it is clear that the consultation duration influences the verbal content of the interaction and that there are "slow" and "fast" doctors." Our survey of the views of anesthesiologists on the key information to be imparted during a preoperative assessment may well be a reflection of this diversity.

Another issue is patient desire for information, surrounding which there is an abundance of literature. ${ }^{10-}$ ${ }^{12}$ It has been shown that the majority of patients wish to meet with the anesthesiologist preoperatively and to be informed about a number of perioperative details, such as anesthetic complications and pain relief. ${ }^{12}$ It has also been shown that there exists some public confusion as to the role of the anesthesiologist. ${ }^{13}$

The "translation" of written material is important in the preparation of any patient educational material, as illiteracy, defined as a reading level below Grade 4, persists in every socio-economic and ethnic group. ${ }^{14}$ The Adult Literacy and Life Skills Survey released in 2005, using data collected by Statistics Canada in 2003 , found that $14 \%$ of adults had Level 1 literacy skills and would be unable to determine simple instructions on a pharmaceutical label. ${ }^{4}$ A further $27 \%$ of the population had Level 2 skills, which indicated that they would have difficulty with "novel concepts". Inadequate functional health literacy also extends to conceptual areas of understanding and has been identified as having adverse direct and indirect effects on heath status. ${ }^{15,16}$ Even in those assumed to have good literacy skills, medical vocabulary is often a barrier to public understanding, irrespective of education level, as medical jargon is considerably specialized. ${ }^{14} \mathrm{We}$ attempted to overcome these barriers to comprehension by writing the booklet at a Grade 6 reading level and using plain language principles. This appears to have been a successful approach as evidenced by our achievement in imparting information about anesthesia to non-Canadian born patients.

We assessed successful knowledge acquisition by means of a questionnaire. While this method is limited in scope, it has been widely used in assessing the impact of educational interventions on patients. ${ }^{3} \mathrm{~A}$ limitation of our assessment of the questionnaire was the limited number of questions asked of patients and the focus on a few key themes. We decided on this approach after a pilot study demonstrated that our ability to engage patients and obtain completed questionnaires would be compromised if the "test" segment of our study was too detailed or too onerous to complete.

Our data suggest that the booklet was a successful patient education tool for a broad range of patients. Patients with different cultural backgrounds often approach health and illness from a perspective that is quite disparate from "Western" views. ${ }^{17}$ Such biases can influence health decisions and impede the process of informed consent. However, our booklet appeared to be effective irrespective of whether or not the patient was born in Canada. Education status did not have a significant impact on booklet comprehension, suggesting that we were successful in developing a booklet suitable for an audience of diverse English reading ability.

Unfortunately, as the Phase I anesthesiologist survey and the Phase II patient questionnaire do not touch upon identical areas of knowledge, we cannot conclude that the booklet successfully standardized patient education by resolving the inconsistencies in current practice. However, it is notable that regardless of when patients saw the anesthesiologist, median scores remained unchanged. This indicates that the booklet was an effective teaching tool in the areas of knowledge tested by the patient questionnaire.

In conclusion, this study suggests that preoperative consultations may not be standardized and that the development of patient information material, at an appropriate reading level, may improve patient understanding about anesthesia and perioperative issues. This approach may be particularly helpful in serving the needs of a multi-ethnic patient population.

\section{Acknowledgement}

The authors thank Dr. Sandy Clanachan for his work with the statistical analysis in this study.

\section{References}

1 Matthey P, Finucane BT, Finegan BA. The attitude of the general public towards preoperative assessment and risks associated with general anesthesia. Can J Anesth 2001; 48: 333-9.

2 Matthey PW, Finegan BA, Finucane BT. The public's fears about and perceptions of regional anesthesia. Reg Anesth Pain Med 2004; 29: 96-101.

3 Lee A, Chui PT, Gin T. Educating patients about anesthesia: a systematic review of randomized controlled trials of media-based interventions. Anesth Analg 2003; 96: 1424-31.

4 ABC CANADA Literacy Foundation. Learning a Living: First results of the Adult Literacy and Life Skills (ALL) Survey. 2005. Report no 89-603-XWE. 
Available from URL; http://www.abc-canada.org/ media_room/news/all_survey_summary.shtml.

5 Delp C, Jones J. Communicating information to patients: the use of cartoon illustrations to improve comprehension of instructions. Acad Emerg Med 1996; 3: 264-70.

6 Cutts $M$. The Plain English Guide. New York: Oxford University Press; 1995.

7 Domino KB, Posner KL, Caplan RA, Cheney FW. Awareness during anesthesia: a closed claims analysis. Anesthesiology 1999: 90: 1053-61.

8 Cheney FW. The American Society of Anesthesiologists Closed Claims Project: what have we learned, how has it affected practice, and how will it affect practice in the future?. Anesthesiology 1999; 91: 552-6.

9 Wilson A. Consultation length in general practice: a review. Br J Gen Pract 1991; 41: 119-22.

10 Garden AL, Merry AF, Holland RL, Petrie KJ. Anaesthesia information - what patients want to know. Anaesth Intensive Care 1996; 24: 594-8.

11 Shevde K, Panagopoulos G. A survey of 800 patients' knowledge, attitudes, and concerns regarding anesthesia. Anesth Analg 1991; 73: 190-8.

12 Lonsdale M, Hutchison GL. Patients' desire for information about anaesthesia. Scottish and Canadian attitudes. Anaesthesia 1991; 46: 410-2.

13 Swinhoe CF, Groves ER. Patients' knowledge of anaesthetic practice and the role of anaesthetists. Anaesthesia 1994; 49: 165-6.

14 Giorgianni SJ. (1998). Responding to the challenge of health literacy. In: Giorgianni SJ (Ed.). The Pfizer Journal. New York: Impact Communications. Available from URL; http://www.thepfizerjournal.com/pdfs/ TPJ04.pdf.

15 Rootman I, Ronson B. Literacy and health research in Canada: where have we been and where should we go? Can J Public Health 2005; 96(Suppl 2): S62-77.

16 Williams $M V$, Parker RM, Baker DW, et al. Inadequate functional health literacy among patients at two public hospitals. JAMA 1995; 274: 1677-82.

17 Suurmond J, Seeleman C. Shared decision-making in an intercultural context. Barriers in the interaction between physicians and immigrant patients. Patient Educ Couns 2006; 60: 253-9. 